\title{
KEDUDUKAN BHINEKA TUNGGAL IKA UNTUK MEMPERKUKUH NEGARA KESATUAN REPUBLIK INDONESIA DI MASA PANDEMI
}

\author{
Triana Devi Fatimah \\ Institut Ilmu Kesehatan STRADA Indonesia
}

25triadevi062003@gmail.com

\begin{abstract}
Abstrak
Artikel ini bertujuan untuk memberi gambaran mengenai kedudukan Bhineka Tunggal Ika di Masa Pandemi Covid-19. Penelitian ini menggunakan kajian studi pustaka. Informasi yang diambil berupa hal-hal yang berkaitan dengan konsep kebhinnekaan dan pandemi Covid-19. Penulis menggunakan metode penelitian kepustakaan dengan menelusuri sumber buku, jurnal, dan sumber internet yang relevan. Sebagai bangsa yang memegang teguh semboyan Bhinneka Tunggal Ika sudah sepatutnya bisa mengamalkan semboyan tersebut dalam berbagai hal situasi yang mengancam robohnya persatuan dan kesatuan bangsa. Kebajikan warga negara dalam bentuk mengamalkan dan mengetahui kedudukan Bhinneka Tunggal Ika di kalangan masyarakat dapat dicapai dengan pengetahuan dan kepedulian masyarakat itu sendiri. Kedudukan Bhinneka Tunggal Ika sangat berperan penting dalam memperkokoh Persatuan dan Kesatuan Negara Republik Indonesia di masa pandemi seperti ini. Dengan menerapkan konsep Bhinneka Tunggal Ika dengan kebersamaan tanpa membeda-bedakan, diharapkan kita dapat bersama-sama melawan Covid-19 tanpa membedakan golongan ataupun latar belakang pekerjaan.
\end{abstract}

\section{Latar Belakang}

Bhinneka Tunggal Ika merupakan semboyan bangsa Indonesia. Semboyan itu untuk menggambarkan persatuan dan kesatuan bangsa yang memiliki nilai-nilai seperti toleransi, moderat, harmoni, integrasi, kerja sama, saling mendukung, semangat berjuang. Implementasi nilai-nilai Pancasila untuk mewujudkan masyarakat bersatu, makmur berkeadilan, dan keadilan yang berkemakmuran dilakukan oleh pemerintah dan seluruh elemen masyarakat yang menghuni wilayah nusantara ini dengan tekad menjaga keutuhan dan persatuan bangsa Indonesia.

Aktualisasi nilai-nilai Bhinneka Tunggal Ika dapat dilakukan melalui tindakan nyata keseharian oleh seluruh komponen negara dalam memperkuat integrasi nasional, karena Indonesia dengan beragam suku/etnik, bahasa, agama, kondisi geografis, dan strata sosial yang berbeda. Semua itu berada di bawah kekauasaan sebuah sistem nasional, termasuk di dalamnya pemerintah menjalankan proses pembangunan masyarakat yang majemuk harus bersinergi bersama tanpa membedakan latar belakang dan strata sosial kehidupan untuk mewujudkan cita-cita bangsa sesuai dengan komitmen bersama berlandaskan nilai-nilai yang terkandung dalam Bhinneka Tunggal Ika yang tetmaktub dalam Pancasila. Ciri kemajemukan bangsa Indonesia yang terintegrasi secara nasional sangat penting sebagai potensi yang dapat dikembangkan dan dimanfaatkan dalam membangun komunikasi serta aksi nyata sebagai acuan utaa jati diri bangsa Indonesia untuk menunjukan sikap nasionalisme guna mempertahankan Negara Kesatuan Republik Indonesia.

Jika persatuan nasional tidak ada, karena alasan apapun, maka komplik adalah hasil yang mungkin digunakan untuk menunjukkan penyatuan berbagai kelompok orang yang disatukan oleh karakteristik khusus di wilayah geografis dan memiliki otoritas politik. 
Peningkatan pemahaman masyarakat terhadap kemajemukan sosial budaya akan berkontribusi pada semakin dewasanya pola pikir dan sikap masyarakat membangun citra diri didasarkan aktualisasi pemahaman nilai-nilai kebhinnekaan yang dimiliki, dapat menjadi investasi yang diandalkan pada pelaksanaan pembangunan nasional sebagai salah satu pilar demokrasi. Untuk itu diharapkan tindakan nyata pemerintah dan masyarakat yang lebih kompak terutama pada masa pandemi seperti ini. Penanganan Covid-19 telah dikeluarkan Intruksi Presiden Republik Indonesia Nomor 6 Tahun 2020 tentang peningkatan disiplin dan penegakan hukum protokol kesehatan dalam pencegahan dan pengendalian Covid-19 agar masyarakat terlindung dari corona virus. Penerapkan protokol kesehatan 4M, yakni memakai masker, mencuci tangan, menjaga jarak, dan menghindari kerumunan agar terhindar dari Covid-19. Seruan ini tanpa membedakan suku, agama, ras, adat istiadat, latar belakang geografis, status sosial, kedudukan dan seterusnya, yang fungsinya melindungi manusia sebagai warga negara agar tetap sehat.

Dengan semboyan Bhinneka Tunggal Ika, diharapkan menjadi landasaran perjuangan pemerintah dan masyarakat untuk mewujudkan persatuan serta kesatuan bangsa Indonesia. Sehingga bangsa Indonesia selalu harmonis, toleran akan perbedaan, menjaga keutuhan bangsa, dan pada akhirnya menjadi kiblat dunia sebagai bangsa yang multikulturalisme. Bhinneka Tunggal Ika adalah moto atau semboyan bangsa Indonesia yang memiliki arti walaupun berbeda-beda tetapi tetap satu jua. Ungkapan Bhineka Tunggal Ika dapat ditemukan dalam kitab Sutasoma, yang ditulis oleh Empu Tantular pada abad XIV di masa kerajaan Majapahit. Tulisan Bhineka Tunggal Ika terdapat di bawah lambang Garuda Pancasila yang secara resmi dipakai dalam sidang kabinet Republik Indonesia Serikat pada tanggal 11 Februari 1950 yang dipimpin oleh Moh. Hatta. Terjemahan persatuan bangsa dan wilayah negara Indonesia kemudian disimpulkan dalam peraturan pemerintah No. 66 tahun 1951 tentang lambang negara Republik Indonesia.

Semboyan Bhinneka Tunggal Ika memuat dua konsep yang berbeda, bahkan kedua konsep tersebut seolah-olah bersifat kontradiktif. Kedua konsep itu adalah "Bhineka" dan "Tunggal Ika". Konsep Bhineka mengakui adanya keanekaragaman atau keragaman, sedangkan konsep Tunggal Ika menginginkan adanya kesatuan. Keanekaragaman dicirikan oleh adanya perbedaan, sedangkan kesatuan dicirikan oleh adanya kesamaan. Jika kedua hal tersebut dipahami dan dilaksanakan dengan tekanan yang berbeda (tidak seimbang), maka akan dapat menimbulkan kondisi yang berbeda pula. Adanya dua konsep yang berbeda tersebut menunjukkan bahwa semboyan Bhinneka Tunggal Ika mengandung problem metafisika, yaitu problem antara kepelbagian dan kesatuan, problem antara hal banyak (the many) dan hal satu (the one). Berdasarkan problema tersebut tampak bahwa untuk mencari makna Bhinneka Tunggal Ika diperlukan adanya perenungan mendalam yang bersifat filosofis metafisis.

Negara Kesatuan sering disebut negara unitaris atau unity, yaitu negara tunggal yang monosentris (berpusat satu). Dalam negara kesatuan hanya ada satu konstitusi, satu kepala negara dan satu badan legislatif yang berlaku bagi seluruh wilayah negara. Hakikat negara kesatuan yang sesungguhnya adalah kedaulatan tidak terbagi-bagi baik keluar maupun ke dalam dan kekuasaan pemerintah pusat tidak dibatasi. Pembentukan negara kesatuan bertujuan untuk menyatukan seluruh wilayah Nusantara agar menjadi warga negara yang besar dan kokoh dengan kekuasaan negara yang bersifat sentralistis.

Bangunan negara kesatuan (unitaris), hanya ada satu kekuasaan yang berwenang untuk membuat Undang-Undang yang berlaku di negara tersebut, yakni pemerintah pusat. Sementara pemerintah daerah hanya melaksanakan atau menyesuaikan Undang-Undang tersebut dengan keadaan sekitar. Sehingga jika ada kewenangan pembentukan peraturan 
perundang-undangan ditingkat daerah, hal itu merupakan kewenangan yang bersumber pada distribusi maupun atribusi kewenangan. Sehubungan dengan hal itu, maka dikenal adanya model negara kesatuan yang ditinjau dari asas penyelenggaraan pemerintah, yaitu negara kesatuan dengan asas sentralisasi dan negara kesatuan dengan asas desentralisasi.

Pandemi Covid-19 juga dikenal sebagai pandemi virus corona merupakan lanjutan pandemi dari penyakit virus corona yang disebabkan oleh akut sindrom pernafasan corona virus 2 (SARS-CoV-2). Pertama kali teridentifikasi pada Desember 2019 di Wuhan, China. The World Health Organization (WHO) menyatakan wabah sebuah Kesehatan Darurat Masyarakat Peduli Internasional pada bulan Januari 2020 dan pandemi Maret 2020. Di Indonesia sendiri virus ini hadir sejak awal Maret 2020. Penyakit corona virus ini menyerang saluran pernafasan yang menular (Putri, 2020). Virus yang menyebabkan Covid-19 terutama ditransmisikan melalui droplet (percikan air liur) yang dihasilkan saat orang terinfeksi batuk, bersin, atau menghembuskan nafas. Droplet ini terlalu berat dan tidak bisa tahan di udara, sehingga dengan cepat jatuh dan menempel pada lantai atau permukaan lainnya.

Virus ini dapat menular saat menghirup udara yang mengandung virus jika terlalu dekat dengan orang yang sudah terkonfirmasi positif Covid-19. Selain itu, virus ini dapat menula jika menyentuh permukaan benda yang terkontaminasi lalu menyentuh mata, hidung, atau mulut. Menurut WHO (World Health Organization) Pandemi adalah penyebaran penyakit baru ke seluruh dunia (World Health Organization, 2020). Namun, tidak ada definisi yang dapat diterima tentang istilah pandemi secara rinci dan lengkap, beberapa pakar mempertimbangkan definisi berdasarkan penyakit yang secara umum dikatakan pandemi dan mencoba mempelajari penyakit dengan memeriksa kesamaan dan perbedaannya. Penyakit dipilih secara empiris untuk mencerminkan spektrum etiologi, mekanisme penyebaran, dan era kegawatdaruratannya, beberapa penyakit yang pernah menjadi pandemi antara lain: Acute hemorrhagic conjunctivitis (AHC), AIDS, kolera, demam berdarah, influenza dan SARS.

Terhitung sejak awal Januari 2020, dunia mengalami pandemi hebat yang Covid-19. Pada saat ini masyarakat tengah diposisikan dengan virus corona yang tidak memungkinkan untuk aktivitas di luar rumah. Peran masyarakat sangat penting dalam kondisi seperti ini, sebelumnya masyarakat dapat beraktivitas dengan leluasa diluar rumah, sdangkan sekarang hanya dapat berdiam di rumah saja. Menularnya Covid-19 membuat dunia menjadi resah, termasuk Indonesian.

\section{Kasus/Masalah}

Bagaimana kedudukan bhineka tunggal untuk memperkukuh negera kesatuan republik Indonesia di masa pandemi?

\section{Tinjauan Pustaka}

a. Definisi Persatuan dan Kesatuan Indonesia

Menerut Kamus Besar Bahasa Indonesia (KBBI), persatuan adalah gabungan (ikatan, kumpulan, dan sebagaiannya) beberapa bagian yang sudah bersatu. Sementara kesatuan adalah perihal satu. Keesaan yang bersifat tunggal. Berdasarkan istilah, persatuan dan kesatuan berasal dari satu kata yang berati utuh atau tidak terpecah belah. Dikutip situs Kementerian Pendidikan dan Kebudayaan (Kemendikbud), persatuan dapat diartikan sebagai perkumpulan dari berbagai komponen yang membentuk menjadi satu. Sedangkan kesatuan merupakan hasil perkumpulan tersebut 
yang telah menjadi satu dan utuh. Maka kesatuan erat hubungannya dengan keutuhan. Sehingga persatuan dan kesatuan mengandung arti bersatunya macam-macam corak yang beraneka ragam menjadi satu kebulatan yang utuh dan serasi. Persatuan dan $\mathrm{m}$ kesatuan bangsa tumbuh dari unsur-unsur sosial budaya masyarakat Indonesia sendiri.

b. Persatuan dan Kesatuan

Kebudayaan-kebudayaan dari luar juga masuk ke Indonesia melalui proses akulturasi (percampuran kebudayaan).Kebudayaan dari luar yang masuk ke Indonesia itu meliputi kebudayaan Hindu, Islam, Kristen, dan unsur-unsur kebudayaan lain. Itu menjadikan kebudayaan di Indonesia semakin beragam. Namun kebudayaan dari luar tidak sembarangan masuk ke Indonesia. Ada seleksi terlebih dahulu. Dalam setiap pengambilan keputusan yang menyangkut kehidupan bersama dilakukan dengan jalan musyawarah dan mufakat. Itulah yang mendorong terwujudnya persatuan dan kesatuan bangsa Indonesia.Unsur-unsur sosial budaya seperti, jiwa gotong royong, sifat kekeluargaan. Itu merupakan sifat-sifat pokok bangsa Indonesia yang dituntun oleh asas kemanusiaan dan kebudayaan. Menjalin kebersamaan dan saling melengkapi harus dilakukan oleh bangsa Indonesia. Itu adalah cara terbaik untuk dapat mempertahankan persatuan bangsa dari adanya ancaman perpecahan antar anggota masyarakat. Sikap toleransi juga harus dijunjung tinggi oleh masyarakat. Karena Indonesia terdiri dari beragam suku, budaya, etnis, maupun agama.

c. Prinsip Persatuan dan Kesatuan

1. Bhineka Tunggal Ika

Bhineka tunggal ika memiliki arti berbeda-beda tapi tetap satu. Indonesia adalah negara beragam. Sehingga masyarakat harus mengakui jika Indonesia negara yang beragam dan tetap satu sebagai bangsa Indonesia.

2. Nasionalisme Indonesia

Nasionalisme adalah paham atau ajaran untuk mencintai bangsa dan negara sendiri. Setiap warga negara harus memiliki rasa nasionalisme dan itu sangat penting.

3. Kebebasan yang bertanggung jawab

Setiap manusia harus memiliki kebebasan dan tanggung jawab bagi dirinya, sesama, negara dan Tuhan Yang Maha Esa.

4. Wawasan Nusantara

Adanya wawasan nusantara, maka tiap orang akan merasa satu, senasib sepenanggungan. Pada wawasan nusantara ditempatkan dalam kerangka kesatuan politik, sosial, budaya, ekonomi, dan pertahanan keamanan.

5. Persatuan Pembangunan untuk mewujudkan cita-cita reformasi Dengan persatuan pembangunan, maka setiap orang bisa mengisi kemerdekaan dan melanjutkan pembangunan.

\section{Pembahasan}

Bhinneka Tunggal Ika merupakan semboyan yang tertera dalam lambang negara Indonesia, pancasila. Bhinneka Tunggal Ika merupakan semboyan bangsa yang harus dijunjung tinggi kedudukannya. Bhinneka Tunggal Ika disebut sebagai ikrar pemersatu bangsa yang menggetarkan jiwa. Semboyan ini menggambarkan persatuan dan kesatuan 
bangsa Indonesia, yang memiliki keberagaman suku bangsa, budaya, bahasa daerah, agama dan kepercayaan, ras maupun antargolongan. Semboyan Bhineka Tunggal Ika menunjukkan bukti keanekaragaman Indonesia yang patut dijunjung tinggi, serta saling menghargai perbedaan.

Perbedaan bukan alasan untuk saling memecah belah ikatan persaudaraan. Meski sangat beragam, bangsa Indonesia tetap satu kesatuan yang tidak bisa dipisahkan. Di sinilah arti Bhinneka Tunggal Ika yang sesungguhnya. Bhinneka Tunggal Ika jika diterjemahkan memiliki arti berbeda-beda tetapi tetap satu jua. Ikrar sederhana yang penuh makna ini diambil dari kitab Sutasoma karya Mpu Tantular. Bhineka Tunggal Ika diambil dari kitab atau Kakawin Sutasoma karangan Empu Tantular, yang hidup pada masa Kerajaan Majapahit sekitar abad ke-14 M. Melalui semboyan ini, Indonesia bisa dipersatukan dan semua keberagaman tersebut menjadi satu bagian dari Negara Kesatuan Republik Indonesia (NKRI).

Hal ini menggambarkan persatuan dan kesatuan yang terjadi di wilayah Indonesia, dengan keberagaman penduduk Indonesia yang terdiri dari bermacam-macam suku, bahasa daerah, ras, agama, dan kepercayaan, tidak membuat Indonesia menjadi terpecah. Atas segala macam perbedaan inilah kemudian Bhinneka Tunggal Ika dibentuk. Sejarah terbentuknya Bhinneka Tunggal Ika jelas penting sekali. Semboyan Bhinneka Tunggal Ika dikenal untuk kali pertama pada masa Majapahit era kepemimpinan Wisnuwardhana sekitar abad ke-14 M. Bhinneka Tunggal Ika merupakan kutipan dari sebuah kakawin Jawa Kuno, yang lebih dikenal sebagai kitab Sutasoma. Kutipan ini berasal dari pupuh 139, bait 5. Hartaka\& Suadnyana (2020) menulis baitnya sebagai berikut:

Rwaneka dhatu winuwus Buddha Wiswa,

Bhinneki rakwa ring apan kena parwanosen,

Mangka ng Jinatwa kalawan Siwatatwa tunggal,

Bhinneka tunggal ika tan hana dharma mangrwa

Artinya:

Konon Buddha dan Siwa merupakan dua zat yang berbeda.

Mereka memang berbeda, tetapi bagaimanakah bisa dikenali,

Sebab kebenaran Jina (Buddha) dan Siwa adalah tunggal.

Terpecah belahlah itu, tetapi satu jugalah itu. Tidak ada kerancuan dalam kebenaran.

Hal tersebut memberi makna inspiratif bagi bangsa Indonesia. Indonesia ketika itu masih memegang kuat kepercayaan Hindu dan Budha serta menggunakan bahasa Sanskerta dalam penulisan. Perumusan semboyan ini didasari keberagaman di berbagai pulau dan wilayah yang tersebar di Indonesia. Seluruh perbedaan budaya, suku, kepercayaan dan masih banyak lagi, semuanya mengarah pada persatuan. Semangat toleransi dengan menjunjung tinggi Bhinneka Tunggal Ika, sebagai bentuk sikap menghargai setiap perbedaan.

Sebelumnya, semboyan yang dijadikan semboyan resmi Negara Indonesia sangat panjang yaitu Bhinneka Tunggal Ika Tan Hana Dharma Mangrwa.

Bangsa Indonesia sudah lama hidup di dalam keanekaragaman. Bangsa Indonesia merupakan suatu bangsa yang besar dan berdaulat. Adapun beberapa fungsi dari Bhinneka Tunggal Ika dalam berbangsa maupun bermasyarakat, yaitu: (1) menciptakan dan menjaga 
kesatuan Republik Indonesia; (2) membangun kehidupan nasional yang toleran; (3) sebagai rambu-rambu peraturan dan kebijakan manusia; (4) membantu mewujudkan cita-cita leluhur bangsa; (5) membentengi perdamaian Indonesia. Itulah alasan mengapa, Bhinneka Tunggal Ika patut dijadikan sebagai landasan untuk mewujudkan persatuan dan kesatuan di dalam bangsa Indonesia. Kita sebagai generasi selanjutnya yang bisa menikmati kemerdekaan dengan mudah, harus bersungguh-sungguh untuk menerapkannya dalam kehidupan seharihari. Semboyan Bhinneka Tunggal Ika memiliki makna sebagai alat pemersatu bangsa Indonesia.

Dilihat dari situasi dan kondisi Indonesia saat ini, dimana sedang terjadi wabah yang begitu merugikan masyarakat. Berbagai masalah hadir dampak terjadinya pandemi ini. Salah satu dampat yang paling menonjol yaitu mengenai kondisi ekonomi di Indonesia. Indonesi saat ini terkena dampak pandemi virus baru, bahkan bukan hanya di Indonesia tetapi secara global di berbagai negara telah terkena dampak yang sangat hebat dari virus ini. Pandemi ini akan berdampak secara sosial dan ekonomi. Dalam hal ini, Indonesia harus bersiap siaga dalam menghadapinya terutama dalam hal sistem kesehatan yang ada.

Status siaga darurat adalah keadaan ketika potensi ancaman bencana sudah mengarah pada terjadinya bencana, yang ditandai dengan adanya informasi peningkatan ancaman berdasarkan sistem peringatan dini yang diberlakukan dan pertimbangan dampak yang akan terjadi di masyarakat. Indonesia perlu siaga dan tanggap dikarenakan Covid 19 ini telah ditetapkan sebagai pandemi. Dampak yang ditimbulkan akansangat meluas mulai dari politik, ekonomi, sosial, budaya, pertahanan dan keamanan, serta kesejahteraan masyarakat. Dalam hal ini Indonesia tidak bisa hanya mengandalkan petugas kesehatan dan sarana prasarana saja, tetapi harus melibatkan masyarakat serta sistem kesehatan yang mendukung.

Dampak yang terjadi akibat pandemi Covid-19 di Indonesia sangatlah beragam. Sektor yang paling menonjol adalah bidang ekonomi dan sosial. Di bidang ekonomi terjadi banyak sekali problematika diantaranya, meningkatnya pengangguran karena omset perusahaan menurun, keluarga yang tidak sejahtera karena tidak berpenghasilan. Akibat dari hal tersebut menjalar dan menimbulkan masalah lain yang baru, seperti meningkatnya tingkat Kekerasan Dalam Rumah Tangga (KDRT) sehingga tingkat perceraian di masa pandemi sangat tinggi. Beberapa diantara kasus perceraian itu penyebabnya merupakan masalah ekonomi.

Permasalahan ekonomi yang terjadi akibat pandemi Covid-19 dapat dilihat dari dua sudut pandang ekonomi yang berbeda, yaitu penawaran dan permintaan. Dari sisi permintaan, kondisi pandemi Covid-19 jelas akan mengurangi sektor konsumsi, kegiatan perjalanan dan transportasi, serta perdagangan. Sedangkan dari sisi penawaran, kemungkinan besar yang terjadi adalah terkontraksinya produktivitas pekerja/buruh, penurunan investasi dan kegiatan Pendanaan, serta terganggunya rantai pasokan global.

Dampak yang terjadi di bidang sosial sangatlah beragam. Jelas sekali jika masyarakat kurang berinteraksi dengan orang lain karena pemerintah menganjurkan untuk di rumah saja. Selama di rumah, tak sedikit diantara masyarakat yang memanfaatkan media sosial untuk menjalin hubungan sosial dengan orang lain. Namun, tak sedikit pula yang justru memanfaatkan media sosial untuk kepentingan pribadi yang merugikan orang lain, misalnya penipuan, cyber bullying. Yang paling marak terjadi adalah cyber bullying. Pelaku tak menyadari bahwa yang dia lakukan telah menyakiti dan merugikan orang lain, tak jarang orang-orang korban cyber bullying ini mereasa tak percaya diri, bahkan tak sedikit yang kesehatan mentalnya terganggu, hingga stres. 
Akibat dari berbagai hal tersebut, tak jarang terjadi perpecahan. Maka dari itu, kita tindak lanjuti intruksi Presiden Republik Indonesia Nomor 6 Tahun 2020 tentang peningkatan disipilin dan penegakan hukum protokol kesehatan dalam pencegahan dan pengendalian Covid-19 agar masyarakat terlindung dari corona virus dengan menerapkan protokol kesehatan 4M, yakni memakai masker, mencuci tangan, menjaga jarak, dan menghindari kerumunan agar terhindar dari Covid-19. Seruan ini tanpa membedakan suku, agama, ras, adat istiadat, latar belakang geografis, status sosial, kedudukan dan seterusnya, yang fungsinya melindungi manusia sebagai warga negara agar tetap sehat.

Dengan adanya intruksi tersebut, kita bersama-sama melawan Covid-19 demi mengembalikan nilai-nilai sosial ekonomi Indonesia pada keadaan semula. Dengan semboyan Bhinneka Tunggal Ika diharapkan menjadi landasan pejuangan pemerintah dan masyarakat untuk memperkokoh persatuan serta kesatuan Negara Republik Indonesia dalam menghadapi pandemi Covid-19. Jadi Bhinneka Tunggal Ika mempunyai banyak peran penting dalam kemajuan, kemakmuran, serta keamanan bangsa Indonesia serta keamanan bangsa Indonesia dalam menghadapi pandemi Covid-19. Peran Bhinneka Tunggal Ika yang paling penting atau utama adalah sebagai pemersatu bangsa untuk menjaga derajat dan martabat bangsa.

\section{Simpulan}

Pada saat ini masyarakat tengah diposisikan dengan virus corona yang tidak memungkinkan untuk aktivitas di luar rumah. Peran masyarakat sangat penting dalam kondisi seperti ini, sebelumnya masyarakat dapat beraktivitas dengan leluasa diluar rumah, sdangkan sekarang hanya dapat berdiam di rumah saja. Penularan Covid-19 membuat dunia menjadi resah, termasuk Indonesian. Pada konteks sekarang, kesadaran sebagai bagian dari masyarakat yang saling mendukung, kesadaran sebagi warga negara sangat dibutuhkan sebagai rasa sadar yang muncul dari hati dan pikiran masyarak untuk bersikap dan melakukan sebuah tindakan. Berdasarkan hasil uraian di atas, dapat disimpulkan bahwa kedudukan Bhinneka Tunggal Ika sangat berperan penting dalam memperkokoh Persatuan dan Kesatuan Negara Republik Indonesia di masa pandemi seperti ini. Dengan menerapkan konsep Bhinneka Tunggal Ika dengan kebersamaan tanpa membeda-bedakan, diharapkan kita dapat bersama-sama melawan Covid-19 tanpa membedakan golongan ataupun latar belakang pekerjaan.

\section{Daftar Pustaka}

Adha, M. M., \& Susanto, E. (2020). Kekuatan Nilai-nilai Pancasila dalam Membangun Kepribadian Masyarakat Indonesia. Al-Adabiya: Jurnal Kebudayaan dan Keagamaan, 15(01), 121-138.

Cahyono, A. S. (2020). Implementasi Model Collaborative Governance Dalam Penyelesaian Pandemi Covid-19. Jurnal Publiciana, 13(1), 83-88.

Gultom, A. F., \& Saragih, E. A. (2021). Beriman di Masa Pandemi. Medan: CV. Sinarta.

Gultom, A. F. Kerapuhan Imajinasi Dalam Politik Kewargaan, The Fragility of Imagination in The Politic of Citizenship.

Handayani, R. T., Arradini, D., Darmayanti, A. T., Widiyanto, A., \& Atmojo, J. T. (2020). Pandemic Covid-19, Body Immunity Response, and Herd Immunity. Jurnal Ilmiah Permas: Jurnal Ilmiah STIKES Kendal, 10(3), 373-380. 
Haq, D. (2019). Peran Puskopsyah Kota Metro Dalam Merevitalisasi Nilai-Nilai Bhinneka Tunggal Ika. Jurnal Dewantara, 6(02), 249-272.

Sodik, M. A., \& Nzilibili, S. M. M. (2017). The Role Of Health Promotion And Family Support With Attitude Of Couples Childbearing Age In Following Family Planning Program In Health. Journal of Global Research in Public Health, 2(2), 82-89.

Sodik, M. A., Suprapto, S. I., \& Pangesti, D. (2013). Faktor-Faktor Yang Berhubungan Dengan Pelaksanaan Pelayanan Prima Pegawai Di Rsui Orpeha Tulungagung. STRADA Jurnal Ilmiah Kesehatan, 2(1), 24-32.

Tule, A. R., Siyoto, S., Dwianggimawati, M. S., \& Sodik, M. A. (2018). The Analysis Factors Affecting Interest In Medication Of Receipt Help Aid Bpjs Participant In Balowerti Public Health Center Kediri City. Journal of Global Research in Public Health, 3(1), 68-75.

Sodik, M. A., \& Setyani, A. T. (2018). Effect of Smoking For Teens Against Behavior and Social Interaction.

Attoriq, S., \& Sodik, M. A. (2018). Pencegahan Dan Pengendalian Infeksi Terkait Pelayanan Kesehatan Di Lahan Praktik.

Sodik, M. A. (2018, September). Analysis of Improved Attitude of Youth in HIV/AIDS Prevention through the Provision of Health Education with Peer Education. In The 2nd Joint International Conferences (Vol. 2, No. 2, pp. 495-502).

Oktoriani, E. N., Sutrisno, J., Mayasari, E., \& Sodik, M. A. (2018). Analysis of medical Record complete flexibility to complete claims of health BPJS RS Baptis Kota Batu. Journal of Global Research in Public Health, 3(1), 46-53.

Siyoto, S., Dwianggimawati, M. S., Sari, D. K., Mufida, R. T., \& Sodik, M. A. (2018). The Effect of Pornography Accessity to Influence Sexual Behavior. Indian Journal of Public Health Research \& Development, 9(12).

Sodik, M. A., Yudhana, A., \& Dwianggimawati, M. S. (2018). Nutritional status and anemia In islamic boarding school adolescent in Kediri City East Java Indonesia. Indonesian Journal of Nutritional Epidemiology and Reproductive, 1(3), 172-176.

Sari, N., Yudhana, A., Wahyuni, C., Rusmawati, A., \& Sodik, M. A. (2018). Family support As a determinant safety riding student behavior in SMKN 2 Kediri. Indian Journal of Physiotherapy and Occupational Therapy-An International Journal, 12(4), 230-234. 